\title{
Displaced Identities: Powerless Rights in Powerful State
}

\author{
${ }^{1}$ Deepti Acharya \\ Department of Political Science faculty of Arts the M.S.. University of baroda
}

\begin{abstract}
The present paper is an attempt to investigate the power of state and the responsibility of its institutions in placing displaced identities to their deserving political identities. State is identified with civilization because it has legitimate mechanism to maintained equilibrium between will (politically organized desires of people) and force (power of state used as influence and coercion) with morality (righteousness). Practices by political apparatus, in favor of maximum equilibrium have profound impact on human life because it entitled individuals with privileges as rights. In this reference one of the academic concerns is to see, who is actually eligible to express desires in form of demands and eventually enjoy the same as rights. Investigation creates categories like haves and have-nots i.e politically placed and displaced identities. Here have-nots are not socially or economically suppressed but are the people who have lost their claim to survive. With the use of secondary sources of literature an attempt has been made to analyze the reasons and consequences of political displacements.
\end{abstract}

Key words: Identity, state, power, territory, citizenship, displace identity, constitution, United Nations

\section{Theoretical Backdrop}

In the process of idealism, happiness of one is placed with humanity towards others. This implies that human beings deserve respect because they are gifted with the virtue of humanity; therefore an effort to attain happiness obviously has a limitation of humanity. With this, obligation on state is to provide rights to respect dignity of all human beings. Simultaneously, arrangements are needed to be justified universally, even with the reality of all natural difference in human ability and behavior. Certainly, with such assertion humanity gets priority over happiness. Such understanding facilitates humanity with a universal declaration that whatever resources (in form of facilities) are promised and are going to be promised by the state will come under the realm of humanity. This confirms that even the weakest deserves to get facilities that are essential for his/her existence. Arguments, in favor of universalisation of rights are strengthened with lessons from the past that endorse requirements of human rights for holistic development of human life. It is instituted that with contemporary patterns of governance, question of rights is becoming more political aided with a strong zest of economy. Since economy depends on the available resources that are limited, it is obvious that the state will take control over it and decide on who should be facilitated for same. Legal management of same is decided with the status of membership. Political interpretations (justice) with economic philosophy (profit) empowered state to take authoritative decisions on the eligibility of membership of a human in a territory. It is decisive power of state to finalize on if an individual is going to be assisted with the promised resources or not. Interestingly, this indicates that individuals are entitled for rights not by the virtue of being human and on the ground of humanity but he/she is on the mercy of identity given by state, i.e. citizenship. Fundamental question is, if depth of humanity needs endorsement, with tag of citizenship? In the absence of political identity are humans beings are not human? Most unfortunate is that in the name of state system, humans are refused to be entitled with humanity if they have no clear political identity. This implies that nature has escorted humans with life giving resources but distribution of same under state made it a privilege for some. Confusions on the sharing of resources have reframed the idea of "identity" that is certainly different than religious or gender identities. Additionally, reconstruction of the power of state, with zero interference of religion makes concept of identity wider. With the excellence of state all identities merged into the single one i.e. political identity known as citizenship, given by state. Authority like this legitimately entitles state to address all classified identities on the bases of their political identity i.e. again citizenship. Since modernity has made civilized arrangements by facilitating people with reference to citizenship, the prime concern of contemporary political systems is to focus more on political identity as key concern of human rights. Under the reflection of universal rights present paper focuses on problems of displaced humans that are suffering because of internal and external ignorance. Paper focuses on artificial differences arising due to different political, social and economic segregations. This further creates a category of "they" as the subject of discrimination, within and outside the state. 


\section{Placing Rights In A State}

Rights are evolved as fundamental conditions on which a community agrees on moral grounds. This includes right to live with dignity, which comprise freedom with equality in all aspects of life. Right with equality is the basic principle of development; it authorizes individuals with certain rights that can preserve happiness for them in all circumstances. Rights in this sense are the responsibilities of the state and are considered as most rational because it is understood as positive requirement of desirable opportunities, essential for growth. However, prime difficulty in practicing the idea is that equilibrium of demands and supply cannot be easily maintained with harmony. Political history reveals that the emergence of rights in modern era is a symbol of human hardships. In the beginning of civilization, limitations were not organizational but were natural. It is argued that rights were not sudden for society but realization of the significance of same has created struggle to attain maximum in one's own favor. This adds into the demand for protection from the aggressions of fellow beings.

According to the classical philosophers like Hobbes, Locke and Rousseau, realization of one or other kind of vulnerability is the real reason for which ideas of rights are thought of and are endorsed equally by powerful as well by the weak. Approval with realized common weaknesses emphasizes on the establishment of state as a negotiator that can confirm a stable social system. It was indeed realized to empower state with extremeness of civil authority that can enable apparatus to protect all inhabitants in all circumstances. Understandings like such obligate state to assure security, mental and physical that is otherwise difficult because before the idea of universal rights, society had worked on the principle of "might is right", where powerful was allowed to exploit weak. It is recommended under one of the perceptive of social contract that in the natural state, absence of legal authorities, strengthened the feeling of vulnerability and further creates environment of absolute distrust, consequently social structure was centralized in muscle where power of one can be anytime challenged by the other. Frequent confrontation of powers creates conflicts in public life that leads to instability and disturbs peace and security in the society. Situation can be assumed as a placed where everybody is powerful but stability of power will always remain suspicious. Universality of peace persistently demands for universality of a system. A feeling of diffidence in public management further instigates a collective wisdom that took initiative to decide on common institutions that preserves authority to make workable common law. These laws are supposed to enhance maximum possible happiness in human life by offering moral political response to the most frequent desires. Process of systematizing society with political values, has encouraged and established moral adjustments on critical issues. All this consents includes moral logics which gives them the status of rights that have wider applications. Consequently, rights are observed as the moral understanding of most rational beings, silently supported by social settings and inclusively worked on by the political settings i.e. state. This demonstrates that prime function of state is to sanction rights with humanity. For the most comprehensive purpose like this, state has to materialize rights by creating effective institutions and organizations that can be declared accountable for the implementation of laws concerning with rights assurances. While deciding on the issue of what human beings "actually" have and what they "ought" to have, state has to decide on its target population,. In the world of politics this identity is known as political identity that is further legitimized as citizenship. Citizenship in this respect investigated that will decide on if state will hold responsibility of him/ her or not. Subject matter is important for the smooth allotment of all those limited opportunities that are seriously taken as claims of rights. This indicates that citizenship will explain that this particular individual is served by the state not simply because he/she is a human but he is privileged with rights because he/she is the citizen of that particular state. Hence, while discussing rights, it is essential to keep in mind that human can have many identities but all public (sometimes even private) identities will be served only under the political identity that is citizenship (Joppe, 2010).

\section{Finding Sense In Political Identities}

While understanding identity it is important to observe that in public domain idea of identity is particularly connected with an acknowledgement from others that is further endorsed by self realization. Human beings have selected a way of living according to which personality of an individual in public domain is often tagged by others and an individual is often known in society by the identity given by others. Founding institutions like family and society are the associations that provide basic identity to an individual. This identity decides his/her role in the society, which is limited and therefore far from contentment. Individual as a part of society is always in search of new identity that can have wider influence, for Hobbes it is an ultimate desire of an individual. Desire, to be influential can be fulfilled only in state because state is the only association of associations that provides a wide platform to perform and can offer glory to an individual, furthering his/her identity. Identities like this are certainly different than the social and economic identities because here he/she is not just a parent or an owner but he/she is a political player whose legitimacy is recognized and accepted by the commons, who are struggling for same identity. This further creates conflicts among individuals, commonly known as struggle for power. 
Aspiration for prominent public life confirms that an individual is more interested in attaining political identity that is legitimized by a state because it will cover and endorse other identities. Historical investigations, exhibit that identity became a subject of state when Aristotle mystified social identities with the political one by segregating social identities between the two i.e. into citizens and non-citizens. Citizens, under his thesis "Polity" are those who are eligible to take active part in decision making (Man and Master), whereas non citizens are those who naturally do not have rationality and wisdom and therefore are not given the status of citizens even though they share territory with citizens on regular basis (women, slaves, and children). Political managements with Aristotelian idea of citizenship seem impractical as political arrangements in Greek citystates were not democratic in nature. With the rise of modernity and democracy, idea of citizenship assumed a wider sense. Simple ancient societies and sub societies turn complicated because state as a stakeholder of political power has established unique patterns of negotiations where self interests are satisfied with the interest management of others. To be part of the negotiations it is very important to have the membership of same. All claims before state are intended to build up an organized capacity that has strong stability to influence others in favor of own. With political identity of citizenship an individual is declared eligible for political participation and assured economic and social empowerment. In this sense citizenship is identified as a fruit of profit which an individual is enjoying as a result of citizenship. For effective justice in a state, it is essential to design citizenship to identify the beneficiaries of the development. However, it is observed that even in all perfect democracies there is always a group of "others" who have missed classification of citizenship, for some knownunknown reasons and therefore are suffering from unrealized injustices within and outside the boundaries.

In modern political arrangements, political identity is a must eligibility to claim resources coming within one territory. Significantly, a state is obligated towards an individual only if he/she is a legal member of the state. This indicates that citizenship is essential not just for participation in social, economic or political life but is extremely important to attain basic requirements like food, cloth and shelter. Therefore, it is essential to analyze identity not just as question of social, political or economic status but it needs to monitor for basic survival. Unfortunately, the trend of discussion in modern times is more on power ranking and hence identity is debated not because it is facing serious denial of basic essentials but as social, political and economical tension between various communities, which is more power centric. There is no contradiction on the idea of legitimized identity given by state; it is undoubtedly a developed virtue for which human beings have struggled to place themselves better than other creators. However, question is if political identity is ever realized as a problem of basic requirements of life itself? As it is mentioned that tag of citizenship is a promise of civilized life, role of state is becoming significant and most influential in legalizing life. Unfortunately, in modern settings of life, legal status of an individual is so much interconnected with rights that the essentials, coming under the category of most essentials are unknowingly missed. It is forgotten scholarly that there are certain needs that are much more fundamental than freedom of action. Some of such essentials are the life giving resources that cannot be framed in legality and therefore are beyond the matter of holding nationality. Unfortunately, in the politics of legality, people living in a common territory are positioned as placed and displaced. Inhuman treatment to displaced identities adds in to the struggle.

\section{Displaced Identities: Within Territory, Between Territories}

It is confirmed that to attain a dignified life, identity of a state is as important as rights itself. Role of state is highly crucial in this respect because it has to entitle political identities with rational arguments. That is further systematized with the allotment of the limited resources among the citizens of the state. This confined that the eligibility of entitlement is the subject of measurement, justified on the bases of the proofs of belongings. This indicates that there are some dimensions that will finalize citizenship. Due to the rigorous process of verification of residency documents that can prove existence, there is a possibility to deny essentials as rights to those who are living within the territory but do not have legal testimony of residency. This further implies that in modern pattern of governance humans are not economically and socially divided into haves and have-nots but they are further divided in to borders that are classified as politically subjective i.e. placed and non subjective to state i.e. displaced. Placed are those whose existence are legitimately endorsed by the state and therefore are receiving state attention in public affairs. Second category is a group that is physically present within or outside the border of state but are not documented as the member of the political community. Due to the serious absence of required documents they are not facilitated for their essentials by the state and therefore treated as non- exists. Modern political philosophy has taken both have-nots and displaced as victim of injustice but while dealing with cases it is seriously required to understand that both the situations have different reasoning and so need separate treatments. Have-nots are identified as one of the class of state that exists but lowly, acceptance of their presence gives hopes that situations can be enhanced by repairing and reconstructing old and biased social and economic structures. But same level of possibilities are not found for non-exists as there is no indication of their existence in any of the state. 
Such displaced identities that are often lost other identities are concludes as effect of two, first is the consequence of displacement by state. It is a situation where an individual is lost his/her identity between two boarders because of conflict and persecution. Category is addressed as refugees, a group of people who are forcefully exit from their community and are bound to live in isolation. Indo-Pak war, Vitamin War and recent crisis in Syria has created displaced coming under this category. Other situation is observed as the result of grave social and economic conditions that puts a group on back foot. These groups (every individual is single) do not possess organized identity in a society and have zero contribution in economy, this raise serious question on their existence within the state as their opinion is no opinion. Clearly they are misplaced within their own state and so are living without a support system called state. This creates a group, living in a territory without holding nationality of same. They are displaced internally and so remained "undocumented" in the expression of the state priorities. Statelessness deprives them from basic facilities because non-existence can't be addressed with a serious policy that can entitle them for leased facilities like food and clothing. Karan community in Burma is the most internally displaced community that is social dislocated and forced to live in jungle (www.burmalibrary.org). Since their population is unplaced in documentation of state they cannot demand for education and employment. This makes their situation grimmer because this declares them undeserving for food, clothing and shelter.

On the other hand people who have lost identity between two territories who figured as refugees are war victims or are the victim of decolonization. Dissolution of states after the first and Second World War demands for new criteria of citizenship, people who did not meet such criteria became asylum -seeker in their own state (e.g. situation of citizens during and after partition of India). Emergence of such situations creates different groups that are exiled from their own state. Consequently, they do not have high choices for civilization, situations arise from the conflicts bound them to settle themselves in between the two borders as refugees or if they want to settle within the territory than they have to hide themselves from rest of the society. In international politics, groups like these are placed in the category of lost identities. Although, both categories are deprived from their right to identity and so of the right to life with dignity, but the pain of both can't be painted as same. It is reasonably observed that undocumented within the territory are more depressed as realization of discrimination in day to day life is deep. They are treated as unwanted by the surroundings, contrast situations of the two placed and displaced increase feeling of victimhood and so of injustice. Additionally, there is a disturbing silence about their critical situation, in globalized world no serious attention is paid to their presence as condition of them is considered as the internal matter of the state - beggars, rag pickers and sex workers (to some extent) are coming under this category. Organized ignorance creates criminal tendency in them and consequently they become the state's enemy. With the limit of sovereign power of state, United Nations can work only for the resettlement of the refugees. It is observed that a state, whether internationally powerful or not, is extremely powerful on deciding the matter of second category that is internally displaced. Situation of other category that is refugees is although better but after analyzing the efforts done in favor of them it is universally concluded that efforts do not match results and hence the situation has not improved. Even the UN Convention on refugees declared in 1951 has failed to improve the situation. Under the effect of convention United Nations as international organization has tried to repair the injustices arising due to territorial conflicts, by placing unidentified people in refugee camps. In the initial years, idea of camps received (under Global refugee policy) respect since it comes as a hope for refugees. Positivity was more towards the commitment of United Nations because it showed serious concerns for them on humanitarian grounds. However, hopes failed when temporary residence of refugee's turnout to permanent and camps put up for them became a permanent society. This creates a situation where they have no right except right to live in undesired conditions. In the absence of force of power even right to existence ascertain by United Nations is meaningless because it has not confirmed life with dignity. United Nations is not enjoying sovereignty over state therefore decisions of states in this matter cannot be controlled through international pressure. Reports by UNHCR (United Nations High Commission for Refugees) on the displaced are horrifying, 44 million people of are counted as displaced, in which 15.2 million are refuges and 28.8 million are internally displaced. (In the absence of regular follow up it is almost impossible to find out the exact number for internally displaced). These displaced groups are often observed as a consequence of civil war, external aggression, but unavoidable fact is that there are displaced who are the victim of religious extremism i.e. Hindus in Pakistan and the suffers of unplanned developments i.e. displacements from Narmada and Kalini dam.

Compassionate conditions of the displaced and power of state on public affairs emphasized more on the reinterpretation of the role of state. Position of state is required to be appraised and explore beyond the question of majorities (have-nots) or minorities (haves). Problem highlights on the rational thinking on deserving and undeserving, which is a real classification of privileged and unprivileged. There is a serious requirement to rethink on allocations of values of rights. It has to be analyzed seriously that rights should be given to whom? Also, the question is that are rights naturally justified by human as being human or it is autonomy of state to 
decide on it. Question is important because at least in new state-nation system it is not humanity that is addressed but it is citizenship that is entertained. Fundamental question is, if state is powerful in all matters?

\section{What Makes State Powerful And Why?}

It is quite clear from the above discussion that the problem of political identity became crisis for people living in a definite territory without acquiring a legal nationality of same. Unfortunately, grave conditions of such people have not improved even after the Universal Declaration of Human Rights for displaced identities. Although, Article 15 of the declaration states that everyone has the right to acquire nationality but same cannot be enforced to the states that are sovereign in nature. Sovereignty of state is defined as the supreme power of state that is realized as unique, unchallenged and undisturbed by any organization.

Historically unchallenged powers of state raise a regular question in politics that what makes state powerful? Is state realized and idealized by all societies for same reasons? To find the reason of state power it is important to find the reason for its rise and existence. The simplest possible answer of the state's existence is found in human nature that is similar in one or the way. Human beings have several emotions and expectations that he/she can express intelligently. So far it is understood from human history that human beings are always in search of a contended life. Individuals seek for contentment not just as a social and political being as Plato and Aristotle define but also as an economic being as Marx interprets. Expectations that are highly combined are carrying the burden of desires like security and wealth that can ascertain reputation. It describes that complexity in human nature not ends with "self" because desires for success is followed by happiness that is highly dependent on the presence of others. To sustain happiness, human being as an individual entered in to family system and secure family by making it a part of society. However, proximity with interests of others produced tensions between self and other. Selfness and otherization of interests classified society in various categories that had tendency of supremacy and separatism. Postulation of state-citizen relationships with logics of social contract theories emphasize that state is authorized to respond unsettled social and economic relationships prevailed in natural state. Theories related to origin of state expressed that the relationships in the natural state were "natural" and therefore were highly subjective in nature. In the absence of legal interpretations, empirical realization of same was difficult. There was a serious requirement of visible collaboration among various communities that can further guide collective actions that can work for the benefit of all in future. Realizing ones benefit was not difficult but the challenge was to define undefined collective interests and establish a legitimate correlation among them. Certainly, in the absence of apparent stake holder, the task was difficult. Political history states that complexity of human civilization a movement that was widened to simplify social, economic and political complexities that were commonly faced by rational humans. State was bedecked with virtue of sovereignty for peaceful settlements. Virtue like this makes it a single stake holder has capacity to amalgamate all categories and classes, found as a result of social and economic clashes in a society (idea is well interpreted by Karl Marx in his work on class struggle). It implies that power of state is not limited with political control over an individual but its authority is equally extended towards social and economic affairs of human life. Power of state is taken as first move towards normalization. Attitude of normalization was more political than social in nature because traditionally settled relationships became political and power became the center of all arrangements. State as the single centre of political power has to set justifiable relationships between society and government and has to decide matters on the same. To reduce complexities and remove confusions, dedication was shown from both the sides, citizens as the subject of state were certain with securities and government was assured with obedience. Confirmed cooperation, periodically shown by human beings supports state in it its complex functioning and provides required brilliance that can further able state assure all those that were earlier not possible.

Certainly, results we are living in are not sudden but are advanced with bitter experiences of past. Civilization has faced many constrains to achieve principles of peace on which everybody agrees. The biggest challenge before the state was to search and implement an idea which is comprehensive and inclusive in nature that can wrap all social, political and economic aspects of human life. With feeling of hesitation, both the parties, citizens as members of politically organized society and state as legitimate institution, agreed to come out from the extreme liberties and power and admit certain limitations on self. In this reference, state is not a cheerful desire of human beings but is accepted only as a last best available option to achieve all those social, economic and political conditions that are relatively considered as superior than to the existing one. Hence, state is a combination of "limited will" (of the citizens) and "unlimited force" (of the state). It constantly exists because of its sense of morality that provides ability to use force against rest that is again to maintain morality of peace. Location of legitimate power in state makes it centric in the study political relations. Political philosophy is arguing for powerful state to maintain law and order and for sure growth of all those associations that are depended on the functioning of the state. Therefore role is demonstrated differently by different scholars. Theories like idealist (Fascism and Nazism as dictatorship) and utilitarianism celebrate statehood because of its usefulness and therefore give it absolute power to rule on its subjects that are living within the territory. 
Similarly, in liberalist views, security is the reason of state. Although Marxist analysis is not in favor of state but the authorized existence of state even in the claimed Marxist states like USSR and China, confirm that the state is definitely the result of virtue of rationality, which encourages humans to be united for firm results. Desires push society more towards development that is understood as best and considered more important than just coming out from the conflicts. To achieve the best in company of state, citizens as subject of state further agrees on some principles that entitle human beings with freedoms. Practice of freedom became virtue of power that an individual is having on his/her own. Conversely, for the assurance of freedom of equality some restrictions are imposed on the ideas of rights. These moralities in dealings are further endorsed by state and acquire the shape of rights. For peaceful coexistence rights are authorized as legal activities of individuals. With the result of it, they all are collectively getting freedom of actions and limitation on same in form of duties. It concludes that supremacy of state is accepted with respect of common good and common welfare, since it has taken responsibilities of better life that is further assured with the endorsement of rights. These responsibilities are not idealized in extremes, so is limited within the territory branded as idea of citizenship. Although, state has to systematize nationality and preserve it for a larger population that has genuine claims for entitlement of rights but in the deeds of state, instrument of justice became the tool of discrimination that otherwise never been an intention of state. While processing for development, state has ignored a group that is failed to articulate their claims for citizenship. Consequently, they have lost their political identities, only a single virtue that can give legitimacy to their demands in a political society. The recent fact of global world is that with global management of politics communities are identified as minority or majority and later facilitate with the card of nationality. This means those who are not holders of nationality can't be facilitate, here state is successfully showing their legal limitation and ignoring the major aspects of humanity.

\section{Displaced Identities: Powerless People In Powerful World}

Idea of globalization and practice of democracy has made a powerful world that has most influential apparatus. Significantly, in a functional democracy, system of rights are justified with constitutional limitations, here restrictions are not observed as the power of the state but limitations are inculcated with moral adjustments of duties to conquer sustainable justice. In such systems, political power of a state is not lying in the hand of one individual or group of elite but it is inclusively arranged to be execute by the group of the people. Hence, power of state in a democracy indicates towards inclusive governance that is further understood in the favor of all, means complete absence of discrimination. On the other hand concept of globalization is trying to strengthen international organization by encouraging social, cultural, economic and political inactions between the member states. It preserves that democracy is repairing inner injustice while globalization is busy in settling external imbalances. Modern ways of theorization are mesmerizing, but reality does not match the situation of displaced identities. Although, democratic principles have serious concerns for the most common people but compact idea of citizenship does not include those who are lost in the process of categorization of citizenship and consequently lost identity within the territory. Similarly, although idea of globalization has removed the territorial rigidness by adopting liberalized views especially in economic affairs but is fail to address the problem of those who are displaced due to the political affairs. It is sad to observe that in the process of modernization both democracy and globalization are failed to control the politics of "otherization" that is against humanity in the context of displaced identities. In global scenario displaced are always treated as others and therefore are not seriously considered by any of the state. Humanity gets disturb from this planned ignorance and often raise voice as what these people are getting as being a part of human society? Anxiety is more for blind approach, followed to recognize and tackle these identities. In process of development, these groups are unidentified and therefore discussed just as figures completely unmanaged. Unfortunately, none of the governments is taking this subject as an issue of existence, common negligence creates a world which exists with non- existence and therefore is restricted to use resources. Consequently, they have no permanent solution for the problems like food, cloth and shelter. Externally displaced are dependent on the United Nations for their basic needs like food and cloths, even to get drinkable water they have to walk for miles. Unfortunately, spotted locations where refuges are relocated have no sign of civilization. There is no sign of any system. Arrangements made done by United Nations are far from the facilities like bathrooms, sanitations, schools and hospital. In these grim conditions discussions on justice as right became paradoxical; there is actually no care even for the fundament needs. Irony is rights are claimed to be given without creating civilized surroundings. In the grim absence of systematic support, life became identical of pain for them because desire for life is dying without sustainability of same. Although, there are no separate sufferings for men and women but situation of women and children is definitely worst in comparison to men. Vulnerability to sexual violence and exploitation of children is common; tension realized more in the areas that are overcrowded. Single women or unaccompanied girls in collective centers are at higher risk of abuse or sexual violence. Too often, these women fall victim to traffickers and disappear in the course of the asylum procedure. Since there are no judicial 
authorities, judgment on the criminality is difficult. Absence of effective legal apparatus often leaves them with no redress or consequent in stigmatization and discrimination.

Comparative analysis of the internal and external identities reveled that situation of internally displaced is not different, rather it's even worse than to refugees. History revealed that state has shown least interest in matter of displaced identities. Negative approach towards displaced identities has pushed problem towards NGO's that are essentially working as a supportive body of the government in the welfare function of the state. NGO's are trying to repair situations by providing essential support system like free basic education and prepare them for self employment. However, with all its perfection, efforts are realized as insufficient since their identity of existence is unorganized; it is difficult to identify their location. Those who are in contact with these NGOs are getting at least limited benefit but those who are unaware of it are remaining ignored. Policies made for the displaced is not extensive as they are neither the voters nor the tax payers. They are using resources illegally and therefore often treated as criminals. Propensity is common in case of poor rag- pickers and beggars who are not taken as subaltern but are seen as disturbers. There is certainly a serious problem of governance in both the cases, it is observable that organizations can work only to secure humanity but cannot restore rights for them. Hence, what is done by the organizations will be seen more as a mercy than the right. Absence of balance between right and humanity creates humiliating situations for these refugees. Wide and endless dependence on others creates feeling of subaltern and depression. Programs that are started by national and international organizations, for their economic independence cannot give concrete results since there is no politically organized societies that can be develop in governance. It is ironical to consider that a society, artificially created by international organizations, can enjoy rights without their own government, especially when it is accepted universally that rights needs to be interpreted and protected through the legal apparatus i.e. state. Realities express that these displaced groups are bound to live a life that is incomplete without power of citizenship; this further makes them powerless people in a powerful world.

\section{Conclusion}

Difference of ideology and verity in the pattern of governance brings variation in states identities. This further creates new complications in identity management, where only some people are privileged with resources and many are not. Interpretation, like this puts individual on the mercy of state, thus state is romanticized as free authority that can kill spirit of dignity then and now and can attack on the existence of an individual. Disappointing behavior of states towards displaced identities is primly criticized on the basis of humanity. Results of the analysis are more serious when states fail to provide fundamentals to an individual that are in all cases essential for his/her survival. There is no address for those who are (for any reason) not recognized well by the state. Here crises of identities are not concerned with the rights for growth but issue is highly concerned with the accessibility of minimum essentials for human survival. Unfortunate is that political philosophy has exercised oversight on this issue by merging the two essentials, simple existence and existence with growth. Convictions on extreme lend studies that are far from reality where citizenship is focused more on political benefits in process of which one group of people become a category which has lost their identities in the "culture" of territories. In the process of discussion it is observed that even the most prominent political philosophers have failed to maintain humanity on the management of rights. Human rights are introduced as therapy of human suffering but identities lost in crowd are not found privileged for treatment. Certainly it is time to realize that pain of displace is not political in nature, but it is a question of survival of a human as a human. Nobody knows about the future of those who are born with the displaced identities. It is a question how long humanity should wait for humanity.

\section{References}

[1]. Young, Iris Marion, "Polity and group difference: A critique of the ideal of universal citizenship," Ethics 99 , no.2 1989

[2]. Bart Van Steenbergen (ed.), "The Condition of Citizenship," London: Sage Publications. 1994, Aristotle, The Politics, Start Publications, USA(2012), Walker R. B. J., "Citizenship after the Modern Subject," In Kimberly Hutchings and Ronald Dannreuther (eds.), Cosmopolitan Citizenship. Houndsmill and New York: MacMillan and St. Martin's. 1999

[3]. Fraser, Nancy, "Social Justice in the Age of Identity Politics: Redistribution, Recognition, and Participation," from a Distinguished Lecture at the Centre for Theoretical Studies, Essex University, London. 1999

[4]. Lucy Alba Guerrro, "Internality Displaced Children Constructing Identities, UMI, USA. 2008.

[5]. Lavier Smadar \& Swedenburg Ted, Displacement, Diaspora and Geographies of Identity, (ed), Duke Uni, press, Duke. 2001

[6]. Bammer Angelika, Displacements: Cultural Identities in Question, Association of America Uni press, USA. 1994, WORLD REPORT: Human Right Watch, USA 2002 